\title{
APPLYING KNOWLEDGE MAP FOR JUNIOR CONSTRUCTION ENGINEER
}

\author{
Meng Hsueh Lee \\ Div. of Construction Engineering \& Management \\ Dep, of Civil Engineering, N.T.U. \#1. Resevelt Rd., 4, \\ Taipei 106 Taiwan, R. O. C. \\ Altolee@ntu.edu.tw
}

\author{
H. Ping Tserng \\ Div. of Construction Engineering \& Management \\ Dep, of Civil Engineering, N.T.U. \#1. Resevelt Rd., 4, \\ Taipei 106 Taiwan, R. O. C. \\ hptserng@ntu.edu.tw
}

It is important that how to improve junior engineers efficiently acquire construction project's experience. For junior employee's training, how to effectively reuse the tacit knowledge through information technology becomes an important subject in construction. If the knowledge map could be applied in construction, it would achieve the following spots: (1) enhance the knowledge search efficiency for junior engineer, (2) improve the knowledge reuse in construction, reduce the barrier when construction enterprises implement electronic business, and (3) feed back the experience for developing construction knowledge management system. In order to apply knowledge map in this study, the research will utilize the junior engineer demand with expert interview method, and use the IDEF0 (Integration Definition Function Modeling) methodology to analysis the key factors when junior engineer reuse construction knowledge. Finally, the research will combine the knowledge classification structure, the related documents in construction process, the related websites in internet environment, and knowledge management system to build the individual knowledge map application process for junior engineer.

Keywords: Knowledge Management, Knowledge Map, IDEF0.

\section{INTRODUCTION}

The main purpose in this study is to develop usable learning tool within knowledge map which could translate tacit knowledge become useable evidence knowledge. There are two traditional training methods for junior engineers in construction. One is internal training program, and another is the apprentice learning by senior engineer. The internal training programs usually teach junior engineers basic and fundamental knowledge in construction sites. The apprentice learning by senior engineers usually provide junior engineers who can't learn by training programs, for example: the special skills and experiences in construction project. But most of skills and experiences were easily disappearing when senior engineers promoted, leave job and retirement. Therefore, junior engineers need learning these skills and experiences by themselves for a long time. The project managers will take the risk in construction project if the junior engineers participant without any skills and experiences. Regard to above reason, two topics become important that how to enhance the senior engineers' project skills and experiences and how to translate tacit knowledge turn into useable evidence knowledge for reducing learning time and increasing learning efficiency.

\section{THE RESEARCH SCOPE}

There are many types of projects in construction, for instance office building, bridge, tunnel, airport, etc.; furthermore, there are several phases of project life cycle, for instance planning, bidding, constructing, operating, maintaining. Each type of construction engineering project and each phase of project life cycle need different knowledge. In this study, this research will focus on bridge buildings. Since the bridge buildings are managed by the same owner, government machinery, and the other building are managed by different owner, this research will focus on bridge building. Besides, there are more than twenty-five thousands bridges need maintain per year in Taiwan, the maintenance budget become a huge port of the project life cycle. Therefore, the research will focus on maintenance phase of project life cycle.

\section{LITERATURE REVIEW}

It is necessary and important to study what knowledge map is, and what the junior engineers' knowledge learning problem is during the maintenance phase regard to bridge buildings. The literature review includes two parts. First part includes the background of the knowledge map and the application of knowledge map in construction. Second part includes bridge maintained management issues, for example the bridge management system and the knowledge management websites relating to bridge management and maintenance.

\subsection{Knowledge map}

There are three topic and seven types in knowledge management researches. The first one topic is technology which include System, Cartographic and Engineering; the second one topic is economic which discuss Commercial; and the third one topic is behavioral include Organizational, Spatial, and Strategic. Knowledge map is focusing on the Cartographic type in the technology topic.

Knowledge map is a concept of knowledge searching, which constructs the related between different knowledge. Not only the related of different knowledge, but also used the group mapping to classify different knowledge.

The researches about knowledge map in construction just briefly instruction the concept of dynamic knowledge map and the platform of construction knowledge map 
management system, and construct different ontology to improve the knowledge classify. There are fewer researches to study practical cases in construction project.

\subsection{Bridge maintained management issues}

In Taiwan, the bridge maintaining organization will distribute different resource to various characteristic, priority, and administration. Then the different maintaining organization will have different maintaining result. Table 1 displays the different of characteristic of the bridge, personnel's quality, and budget within several bridge maintaining organizations. In the table 1 , the county and municipal governments manage the most bridge amount, but the least resources. The job of bridge management engineers who were usually part-time engineers and the rate of change job are higher. Therefore the engineer professional skill and experience to maintain the bridge building were scarce.

\subsection{Taiwan bridge administrative system}

The Taiwan Bridge Administrative System was constructed in 2001, and the management organizations were used more than five years. The system is developed more than twenty-five thousands bridge in the database. The Taiwan Bridge Administrative System will supply the history record when administration maintaining the bridge. The main function of the Taiwan Bridge Administrative System is to assist the bridge administration applied the limited resources, keep the bridge structure safety, and raise these bridges service performance. In addition, the process of the bridge maintenance and management include forecast the bridge used demands, evaluate the bridge status, distribute the bridge maintenance budget, set up the bridge maintenance priority, check the higher hazard bridge, discover the reasonable proposal of cost and benefit, calculate the cost of bridge maintenance, track the record of routine maintenance schedule, and create a completed bridge database, and etc.

3.3. The website of bridge maintenance management in Taiwan

In order to analysis the requirement of bridge maintenance management, this research surveyed the website of bridge maintenance management which includes not only public and also private organization in Taiwan. The list about websites had ten sites, that include a: The Maintenance Office in Public Works Department of Taipei City Government, Bridge maintenance management, b: Department of Civil Engineering of National Central University: Center for Bridge Engineering Research, c: National Center for Research on Earthquake Engineering: The bridge maintenance management, d: Paa International Engineering Corporation: Non-fracture Prestressed Automatic Monitoring System, e: The Design Division of National Taiwan Expressway Engineering Bureau: The earthquake harm and emergency strategic of 921 ChiChi Earthquake to the structure of building, f: The website of Ministry of Transportation And Communications: The abstract and document of research project, g: Electric-book: The important bridges reconstruction design and construct of 921 ChiChi Earthquake, h: Taiwan Civil Engineering Technician Labor Union: The research of bridge non-fracture check and safety evaluation.

Table 2 describes the website content, resource, and limit of authority, and the Bridge Maintenance Knowledge Map System (BMKMS) will compare with each website and system.

The difference between BMKMS and other website includes the technology and content of website.

1. The technology of website : The major different on the BMKMS is which could calculate the relation between different documents. This function doesn't like the search engine only used keyword to query database, but used keyword and classify structure to retrieval database.

2. The content of website : The BMKMS doesn't only include the basic content, but also include the structure of knowledge, the content of knowledge, and the cases study of knowledge, knowledge was focus one bridge maintain management.

\section{RESEARCH METHODOLOGY}

Interview and IDEF0 methodology are utilized in this study. Interview is applied to understand people whose inner world motivation and attitude. The people involved in interview include the top managers, project managers, and senior maintenance engineers in the Taiwan Area National Freeway Bureau. The study uses IDEF0 because it can analyze the input, output, mechanism, and control in the knowledge map process. The IDEF0 function analysis tool not only easily builds a hierarchy structure, and also quickly helps junior engineer learning the core process of knowledge map.

\section{RESULT}

The section will discuss the result of bridge maintenance knowledge map within IDEF0 for junior engineer; the knowledge map will contain bridge maintenance classification structure. The literature review shows the skill and experiences for junior engineer include various knowledge. The various skills and experiences include the basic knowledge of bridge maintenance process, the operation of maintenance practice, and the data of bridge maintenance management system. Thus the junior engineers need to spend a lot of time to learning previous knowledge, database system, and information technology system.

The main contribution of the research is defining the detail process to create and use knowledge map for bridge maintenance. The process is based on classification structure, the present operation process, related documents, and the information technology systems (knowledge management system and knowledge map system). The process will raise the performance of learning, lower the 
loading of learning, and share the reusable knowledge for junior engineer.

5.1. The classification structure of bridge maintenance management knowledge

Four classes were developed for bridge maintenance structure based on literature review and interview the master of bridge management in construction industry. The four classes include the history information of bridge, the related rules of bridge maintenance, the mechanism of bridge maintenance and management, and the technology of bridge maintenance and management.

A. The history information of bridge : The study generalize several content of database in the bridge administrative system, which includes the geography data, the maintenance cost of checking information, fundamental information, and the statistic and analysis maintenance record. The bridge administrative system will apply the information to bridge management organization and maintenance organization. Furthermore, the bridge maintenance knowledge map system will integrate with the original function in the bridge administrative system, and increase the classification structure, the related construction website within the bridge maintenance process.

B. The related rules of bridge maintenance : The related rules of bridge maintenance include the law of road of central and regional government for maintenance management process.

C. The mechanism of bridge maintenance and management : The mechanism of bridge maintenance and management include maintenance mechanism, management mechanism, organizational and human resources management mechanism, budget and procurement mechanism. The related mechanisms are in support of the engineers of bridge maintenance management.

D. The technology of bridge maintenance and management : The technology of bridge maintenance and management include upper structure, lower structure, foundation structure, detail structure and assistance facilities.

5.2. Knowledge map integrate bridge maintenance management process

The key factor of integrate knowledge map and process of real task includes the user of knowledge map, the structure of classification, the description of real task, the documents relation of knowledge management system, and the related websites.

In the bridge maintenance management case, the first one factor explains user of knowledge map is the people who manage and execute in the bridge management process. The second factor explains that the structure of classification is similar with the section 5.1. The third factor explains that the description of real task is the detail operation process when engineer maintenance bridge. The forth factor shows that the documents relation mean the system will calculate the relation and similar level within every documents in the database, when user query the system. The final factor illustrates that the related websites are which have important content and information system for bridge maintenance management process.

\section{CONCLUSION}

Knowledge Map is the concept and technology to index the relation between documents. The knowledge map framework in this research not only indexes the relation between documents, but also combines the knowledge classification structure, the related documents in construction process, and the related websites in internet environment. This framework can enhance the learning and training process more efficiently and effectively, and can reduce barrier in organization to implement Knowledge Management in Construction Industry.

\section{REFERENCES}

[1] Carlos H. Caldas, Lucio Soibelman, and Jiawei Han, Automated Classification of Construction Project, ASCE Journal of Computing in Civil Engineering, October 2002.

[2] Chan and Leung, Prototype Web-Based Construction Project Management System, ASCE, Journal if Construction Engineering and Management, Nov/Dec 2004, pp.935-943.

[3] Dany Hajjar and Simaan M. Simaan, INTEGRATING DOCUMENT MANAGEMENT WITH PROJECT AND COMPANY DATA, ASCE, Journal of Computing in Civil Engineering, Jan 2000.pp.70-77.

[4] Gerard Salton, McGill MJ, "Introduction to Modern Information Retrieval," McGraw-Hill New York, 1983.

[5] Jeong-Han Woo, Dynamic Knowledge Map: reusing experts' tacit knowledge in the AEC industry, Automation in Construction 13(2004), PP.203-207.

[6] Jung, Chin and Kim, Informatization Index for Construction Industry, ASCE, Journal of Computing in Civil Engineering, July 2004.pp.267-276.

[7] Michael Earl, Knowledge Management Strategies: Toward a Taxonomy, Journal of Management Information Systems/Summer 2001, vol.18 , No.1 pp.215-233.

[8] Osama Abudayyeh, Assessment of the Computing Component of Civil Engineering Education, ASCE, Journal of Computing in Civil Engineering, July 2004.pp.187-195.

[9] T. E. El-Diraby and F. Briceno, Taxonomy for Outside Plant Construction in Telecommunication Infrastructure: Supporting Knowledge-Based Virtual Teaming, ASCE, Journal of Infrastructure System, June2005 pp.110-121. 
Table 1 - The bridge of each maintains organization analytical table

\begin{tabular}{|c|c|c|c|c|c|c|c|}
\hline \multirow[b]{2}{*}{$\begin{array}{l}\text { Maintain the } \\
\text { organization }\end{array}$} & \multicolumn{3}{|c|}{ Characteristic of the bridge } & \multicolumn{2}{|c|}{ Personnel's quality } & \multicolumn{2}{|l|}{ Budget } \\
\hline & $\begin{array}{l}\text { Grade of } \\
\text { the road }\end{array}$ & $\begin{array}{l}\text { Importanc } \\
\text { e }\end{array}$ & $\begin{array}{l}\text { The } \\
\text { bridge } \\
\text { amount. }\end{array}$ & $\begin{array}{l}\text { Professiona } \\
\text { l Skill }\end{array}$ & $\begin{array}{l}\text { Manpowe } \\
\mathrm{r}\end{array}$ & $\begin{array}{l}\text { Source of the } \\
\text { budget }\end{array}$ & $\begin{array}{l}\text { Common } \\
\text { problem }\end{array}$ \\
\hline $\begin{array}{ll}\text { Taiwan Area } \\
\text { National } \\
\text { Freeway } \\
\text { Bureau }\end{array}$ & $\begin{array}{l}\text { National } \\
\text { road }\end{array}$ & $\begin{array}{l}\text { It is } \\
\text { extremely } \\
\text { important }\end{array}$ & Normal & Good & passable & $\begin{array}{l}\text { Ministry of } \\
\text { Communications }\end{array}$ & \\
\hline $\begin{array}{l}\text { Directorate } \\
\text { General of } \\
\text { highways }\end{array}$ & $\begin{array}{l}\text { Provincia } \\
\text { l highway }\end{array}$ & $\begin{array}{l}\text { It is } \\
\text { important }\end{array}$ & Normal & Good & passable & $\begin{array}{l}\text { Ministry of } \\
\text { Communications }\end{array}$ & \\
\hline $\begin{array}{l}\text { Taiwan } \\
\text { Railway } \\
\text { Administration }\end{array}$ & & $\begin{array}{l}\text { It is } \\
\text { important }\end{array}$ & Normal & Good & passable & $\begin{array}{l}\text { Ministry of } \\
\text { Communications }\end{array}$ & $\begin{array}{l}\text { Slightly } \\
\text { insufficien } \\
\mathrm{t}\end{array}$ \\
\hline $\begin{array}{l}\text { County and } \\
\text { municipal } \\
\text { governments }\end{array}$ & $\begin{array}{l}\text { The } \\
\text { county } \\
\text { road / the } \\
\text { road of } \\
\text { urban } \\
\text { area }\end{array}$ & Normal & $\begin{array}{l}\text { The } \\
\text { most }\end{array}$ & Scarce & $\begin{array}{l}\text { The rate of } \\
\text { change job } \\
\text { is higher. }\end{array}$ & $\begin{array}{l}\text { The pool } \\
\text { distributes the } \\
\text { fund }\end{array}$ & Diverted \\
\hline
\end{tabular}

Table 2: The websites of bridge management and maintenance system compare with BMKMS.

\begin{tabular}{|l|l|l|l|l|l|l|l|l|l|l|}
\hline Note & A. & B. & C. & D. & E. & F. & G. & H. & BMKMS \\
\hline \multirow{5}{*}{$\begin{array}{l}\text { The content } \\
\text { website. }\end{array}$} & The technology of bridge check and evaluation. & $\bullet$ & $\bullet$ & $\bullet$ & $\bullet$ & & $\bullet$ & $\bullet$ & $\bullet$ & $\bullet$ \\
\hline & The technology of bridge maintenance and repair. & & $\bullet$ & $\bullet$ & & $\bullet$ & $\bullet$ & $\bullet$ & & $\bullet$ \\
\hline
\end{tabular}




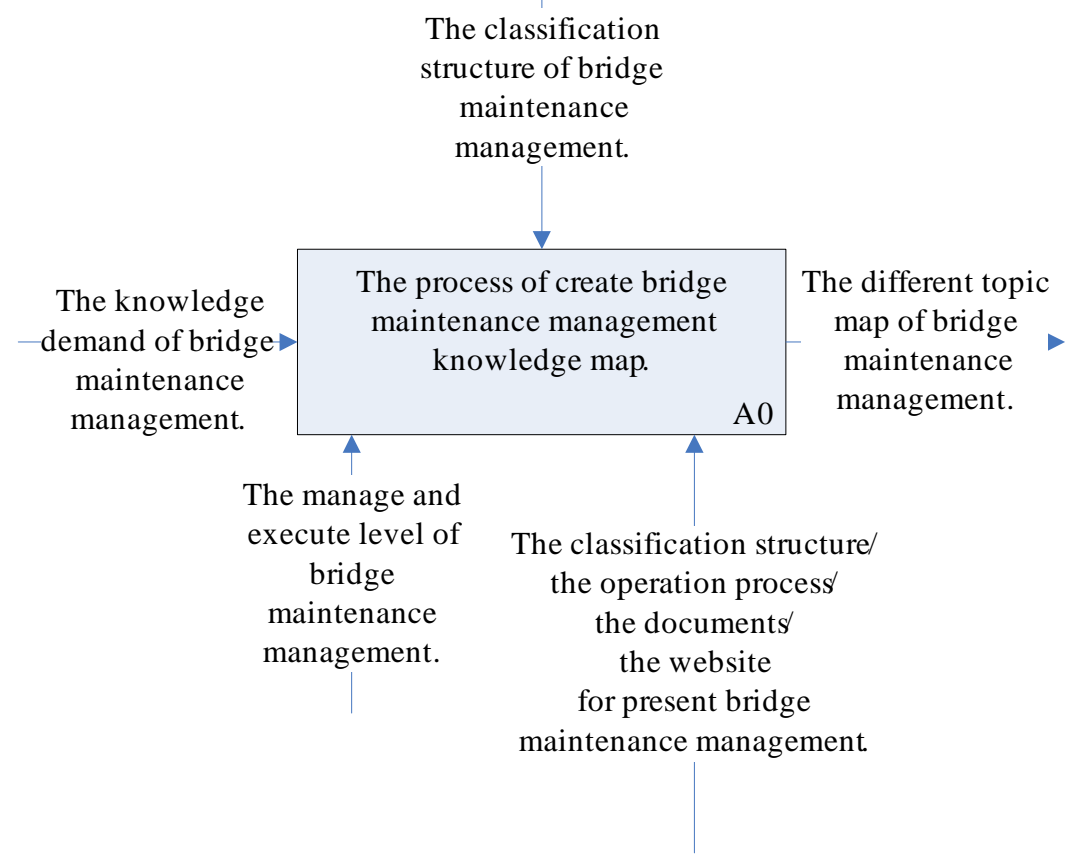

Fig.1 The process of create bridge maintenance management knowledge map using IDEF0 level 1.

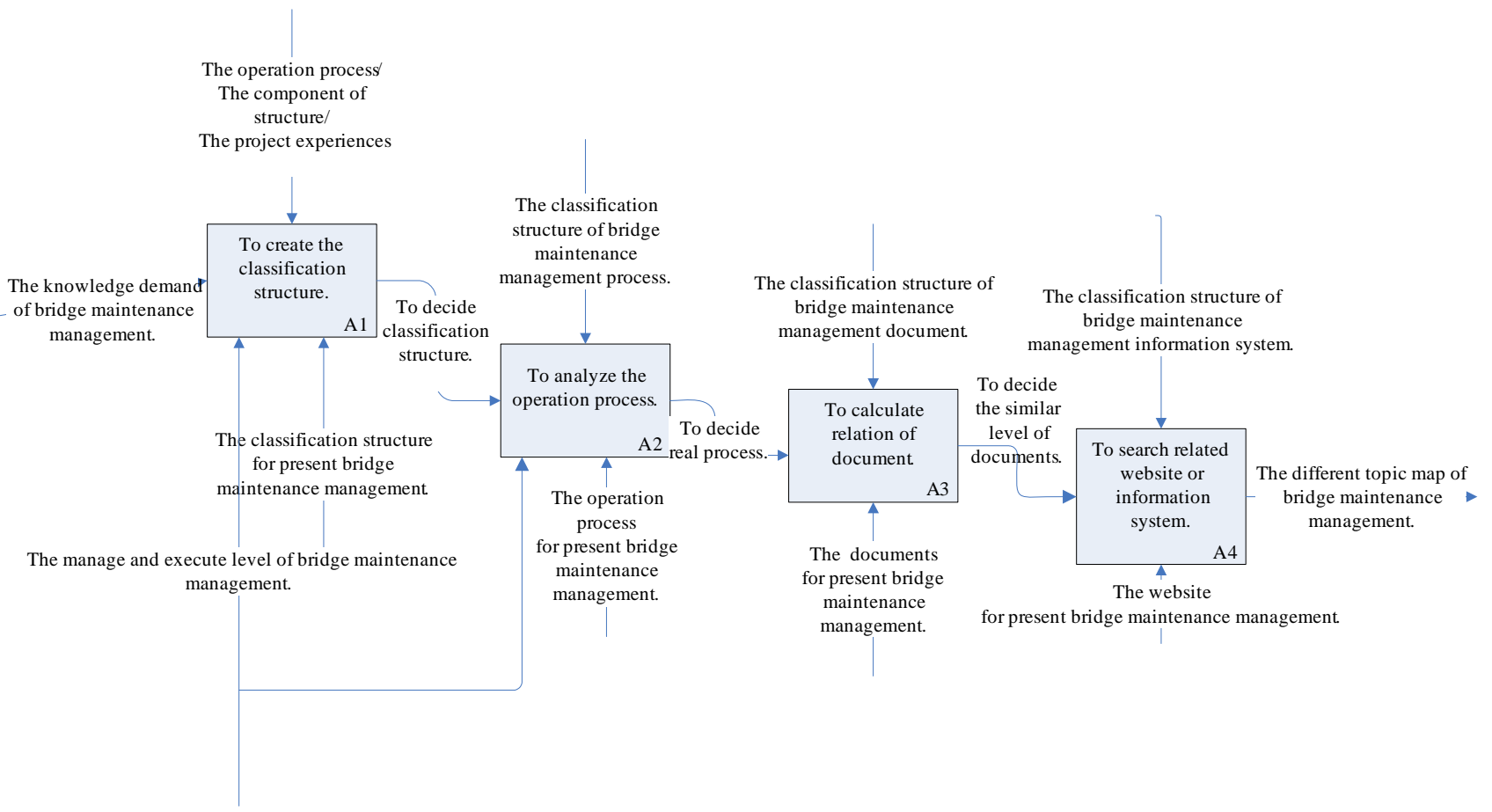

Fig.2 The process of create bridge maintenance management knowledge map using IDEF0 level 2. 